was shown to be in equilibrium between ${ }^{\prime} \mathrm{C}_{4}(58 \%)$ and ${ }^{2} \mathrm{~S}_{11}(42 \%)$.

We have also analysed data for various natural $^{\text {s }}$ or synthetic (J.-C.J., T. Chiba and P.S., unpublished data) glycosides of non-sulphated L-iduronate. A considerable population of the two chair conformers ${ }^{1} \mathrm{C}_{4}$ and ${ }^{4} \mathrm{C}_{1}$ has been found, in this particular case where the $\alpha$-1-iduronate residue is unsubstituted at position 4 . The main difference between the two sets of coupling constants corresponding to the presence of either ${ }^{2} S_{41}$ or ${ }^{4} C_{1}$ lies in the value of $\mathrm{J}_{3,}$ which in the former case remains small, even when $\mathbf{J}_{2.3}$ is quite large.

Finally, 4-unsubstituted glycosides of 2$O$-sulpho- $\alpha$-L-idopyranuronate exist mainly $\left(>90 \%\right.$ ) in the ${ }^{\prime} C_{+}$conformation as also evidenced by the observation of longrange coupling constants $\left(J_{1,3}\right.$ and $J_{2}$ from 0.5 to $1 \mathrm{~Hz}$ ) in synthetic ${ }^{4}$ as well as disaccharides "11 and oligosaccharides (B. Perly and M.P., unpublished data) derived from heparin.

The participation in the conformer equilibrium of $\alpha$-L-iduronate residue located inside a glycosaminoglycan chain of the well-defined ${ }^{2} S_{0}$ skew boat, which results in a quasi-equatorial orientation of its hydroxyl groups, is an equally plausible explanation for the observed susceptibility to periodate oxidation of unsulphated L-iduronate residue in glycosaminoglycans.

Moreover, the unique conformational flexibility of $\alpha$-L-iduronate residues may explain some important binding and related biological properties of dermatan sulphate, heparan sulphate and heparin.

B. Casu*, J. Choayt, D.R. Ferrot, G. Gatti\$, J.-C. Jacouineti, M. Petitout, A. Provasolit,

M. Ragazził, P. Sinay $\|$ \& G. Torri*

* Istituto di Chimica e Biochimica

"G. Ronzoni",

via $G$. Colombo 81 ,

20133 Milano, Italy

+ Institut Choay,

46 Avenue Théophile Gautier,

75782 Paris Cedex 16, France

$\ddagger$ Istituto di Chimica delle

Macromolecole del CNR,

via E. Bassini $15 / A$,

20133 Milano, Italy

$\$$ Bruker Spectrospin, Via Pascoli 70/3, 20133 Milano, Italy

|l Laboratoire de Biochimie Structurale, U.A. 499, U.F.R. de Sciences

Fondamentales et Appliquées, rue de Chartres, B.P. 6759 ,

45067 Orléans Cedex 2, France

1. Rees. D.A.. Morris, E.R.. Stoddart. J.F. \& Stevens. E.S. Nature 317, 480 (1985).

2. Ragazzi. M.. Ferro. D.R. \& Provasoli. A. J. Comput. Chem. 7, 105-112 (1986).

3. Gatti. G.. Casu. B., Homer. G.K.\& Perlin A.S. Macromolecules 12, 1001-1007 (1979)

4. Torri. G. et al. Biochem. biophys. Res. Commun. 128 , $134-140(1985)$

5. Ferro, D. R. et al. J. Am. Chem. Soc, (in the press)

6. Haasnoot. C.A.G., De Leeuw. F.A.A.M. \& Altona. C. Tetrahedron 36, 2783-2792 (1980).
Gatti. G.. Casu. B.. Torri, G. \& Vercellotti. J.R. Carbo hadr. Res. 68, C3-C7 (1979).

8. Sanderson. P.N.. Huckerby. T.N \& Nieduszynski. I.A Gliconconiugate J. 2, 109-120(1985).

Jacquinet. J.C.. Petitou, M. Choay. J. \& Sinaỹ. P. X/hth Intern. Carbohrdr. Simp., Utrecht. 68 (1984).

10. Huchersby. T.N. Sanderson. P.N.\& Nieduzynski. I.A Carbohdr. Res. 138, 199-206 (1985)

\section{Ulcerative rhabdovirus in fish in South-East Asia}

SIR-Annual outbreaks of a severe ulcerative disease with high mortalities of wild and pond cultured freshwater fish have been reported throughout South-East Asia since $1980^{\prime}$. The condition is characterized by the appearance of large, deep ulcers on the body and/or head with varying degrees of destruction of the underlying tissues. Many species are considered to be susceptible but the striped snakehead (Ophicephalus striatus), one of the economically most important species, has perhaps suffered the most severe losses. Pollution of the natural waterways and fish ponds with insecticides and herbicides, particularly paraquat, is believed by some workers to be the major cause of disease whereas others consider the nature, distribution and pattern of spread of the outbreaks to be more consistent with an infective condition.

Between October 1985 and February 1986, wild and pond cultured fish showing varying degrees of skin ulceration were obtained from widely dispersed locations in Thailand and Burma and subjected to virological examination. Portions of liver, kidney and spleen were removed from affected fish, homogenized in Hanks' balanced salt solution, clarified by low-speed centrifugation and the supernatants

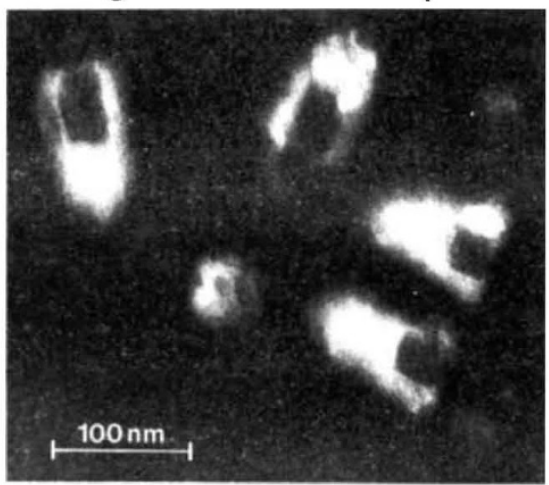

Fig. 1 Rhabdovirus particles from second passage on snakehead cells.

decontaminated by filtration through 450 $\mathrm{nm}$ membrane filters. Monolayer cultures of a cell line derived from snakehead fry were prepared using Leibovitz L-15 medium supplemented with $10 \%$ fetal calf serum as growth medium and $1 \mathrm{ml}$ aliquots of filtered supernatant added to $25 \mathrm{~cm}^{2}$ cultures. After allowing absorption for $1 \mathrm{~h}$ at room temperature the cultures were overlaid with $7 \mathrm{ml}$ maintenance medium (L-15 $+2 \%$ serum) and incubated at $28^{\circ} \mathrm{C}$. Cytopathic effects developed between 3 and 14 days post-inoculation. Cells became granular, rounded up, detached from the monolayer and lysed. This progressed at varying rates over some days until virtual total destruction of the monolayer had occurred leaving only fine, granular debris in the culture medium. Aliquots of media were inoculated onto fresh snakehead cell cultures to confirm transmissibility of the effect.

Electron microscope examination of phosphotungstic acid stained pellets obtained following ultracentrifugation of cell culture fluids from passaged samples revealed bullet-shaped virus particles (Fig. 1). The overall dimensions of these typical rhabdoviruses were $120 \pm 10 \mathrm{~nm} \times$ $80 \pm 5 \mathrm{~nm}$. Morphologically indistinguishable particles were recovered in cell culture from diseased snakeheads from the Bangkok region of central Thailand, Chiang Mai in northern Thailand, Udornthani in northern Thailand and snakehead and freshwater eel (Fluta alba) from the Rangoon area of Burma. The size of the particles corresponds closely with that of other recognized fish-pathogenic rhabdoviruses $^{2-5}$, but further studies are required to determine the relationship of the ulcerative disease isolates to these pathogens.

Although a virus infection has always been recognized as the possible primary cause of disease and virus-like particles of varying morphology have been observed in the tissues of diseased fish", this is the first report of the isolation of a single virus type from more than one species of diseased fish in widely separated geographical areas. However, many diseases of fish cause clinical signs only in adverse environmental conditions and this ulcerative condition seems such a disease. The fact that outbreaks occur in Thailand only during the cooler months of the year suggests that a falling water temperature may be a prime stress factor in this region but other environmental conditions may be precipitating factors elsewhere. Overall we consider the balance of evidence to implicate the rhabdovirus as the likely primary causal agent of the disease.

This work was supported by the UK Overseas Development Administration and FAO. We thank Dr Wattana Wattanavijarn. Chulalongkorn University, Bangkok for facilities and assistance.

G.N.FRERICHS

S.D. Millar

Institute of Aquaculture,

R.J. ROBERTS

University of Stirling,

Stirling FK9 4LA, UK

1. FAO Technical Co-operation Project Rebort 4508 (Depart ment of Fisheries. Ministry of Agriculture and Cooperatives, Bangkok. 1985)

De Kinkelin. P.. Galinard. B. \& Bootsma. R. Nature 241. $465-467(1973)$.

Cohen. J. and Lenoir. G. Ann. Rech. vet. 5, 443-450)(1974) . Hill. B.J., Underword. B.O. Smale. C.J. \& Brown. F. J. gen. Virol. 27, 369-378 (1975)

Ahne. W. Archs Virol 48, 181-185 (1975)

6. Wattanavijarn. W. et al. Thai. J. ver. Med. 13,51-58 (1983): 14. 31-39 (1984). (In Thai). 